\title{
Planomonospora alba sp. nov. and Planomonospora sphaerica sp. nov., Two New Species Isolated from Soil by Baiting Techniques
}

\author{
FREDERICK P. MERTZ* \\ The Lilly Research Laboratories, Eli Lilly \& Company, Indianapolis, Indiana 46285
}

\begin{abstract}
Two new Planomonospora species were isolated from soil by novel baiting techniques. Traditional taxonomic methods and fatty acid analysis techniques were used to establish the identities of these organisms. The names proposed for these new species are Planomonospora sphaerica, whose type strain is strain A51460 (= NRRL 18923), and Planomonospora alba, whose type strain is strain A82600 (= NRRL 18924). The descriptions of these taxa are based on single isolates.
\end{abstract}

Few species of the genus Planomonospora have been isolated and validly described since the original publications of Thiemann and coworkers several years ago $(18,20)$. These microorganisms are extremely rare, exquisitely beautiful, and not readily recognized unless they are examined microscopically. Planomonospora species are uncommon mesophilic organisms that are characterized by small, filamentous, nonfragmenting vegetative hyphae which are 0.6 to $0.8 \mu \mathrm{m}$ in diameter. They grow on complex substrates, such as oatmeal agar, and synthetic substrates, such as glucose-asparagine agar (20). When aerial hyphae are produced, they are usually rose colored. Sporulation varies with the medium used and occurs only on the aerial mycelia. Soluble pigments are rarely produced; melanoid pigments are not formed. Planomonospora species hydrolyze starch but not gelatin; they reduce nitrates to nitrites. The growth temperature is between 22 and $37^{\circ} \mathrm{C}$. These organisms are sensitive to low $\mathrm{pH}$ values. The aerial hyphae bear delicate parallel rows of large sporangia, each of which contains a single large motile sporangiospore. The sporangia are bent in the typical fashion described by Thiemann (20), and each sporangium is attached to the aerial hyphae by a sporangiophore. The genus is characterized by a type III cell wall composition (meso-diaminopimelic acid), a type B whole-cell sugar pattern (madurose), and the absence of mycolic acids. The predominant menaquinones are MK- $9\left(\mathrm{H}_{2}\right.$, $\mathrm{H}_{4}$ ), and the phospholipid type is type PIV (diphosphatidylglycerol, phosphatidylglycerol, phosphatidylinositol, phosphatidylethanolamine, hydroxyphosphatidylethanolamine, and glucosamine-containing phospholipids). The fatty acid pattern type is type 3a (9). The guanine-plus-cytosine content of the DNA is 72 mol\% (9). The antibiotic sporangiomycin (19) and antipain, a protease inhibitor (23), are produced by Planomonospora species.

At present, the genus Planomonospora contains the following species and subspecies: Planomonospora parontospora subsp. parontospora, Planomonospora parontospora subsp. antibiotica, and Planomonospora venezuelensis. The differences between Planomonospora parontospora subsp. parontospora and Planomonospora parontospora subsp. antibiotica, as determined in this taxonomic study, are insignificant; additional investigation needs to be done to validate the taxonomic positions of these taxa. A number of isolates found in this study were identified as strains of Planomonospora parontospora and

* Mailing address: Natural Products Research, Eli Lilly \& Company, Lilly Corporate Center, Indianapolis, IN 46285. Fax: (317) 276-5281.
Planomonospora venezuelensis (see Fig. 5 and 6). In addition, strain $\mathrm{A} 51460^{\mathrm{T}}(\mathrm{T}=$ type strain) was isolated from soil collected in India, and strain $A 82600^{\mathrm{T}}$ was isolated from soil collected in The Sudan. These two strains had properties typical of the genus Planomonospora, yet were different from the previously described Planomonospora species when they were evaluated by traditional taxonomic methods, whole-cell sugar analyses, and a fatty acid analysis. On the basis of chemical, morphological, and physiological properties, I suggest below that strain A51460 $0^{\mathrm{T}}$ is a member of a new species, for which the name Planomonospora sphaerica is proposed, and that strain $\mathrm{A} 82600^{\mathrm{T}}$ is a member of another new species, for which the name Planomonospora alba is proposed.

\section{MATERIALS AND METHODS}

Bacterial strains. Strains A51460 ${ }^{\mathrm{T}}$ and $\mathrm{A} 82600^{\mathrm{T}}$ were isolated from soils by submerging the soils in water enriched for growth of microorganisms with motile spores and using sterile grass blades floating on the water surface as a baiting medium. The following strains were used for comparison: Planomonospora parontospora ATCC $23863^{\mathrm{T}}$, Planomonospora parontospora subsp. antibiotica ATCC $23864^{\mathrm{T}}$, Planomonospora venezuelensis ATCC $23865^{\mathrm{T}}$, Planobispora longispora ATCC $23867^{\mathrm{T}}$, and Planobispora rosea ATCC $23866^{\mathrm{T}}$.

Media. Cells were grown on a rotary shaker at $250 \mathrm{rpm}$ for $72 \mathrm{~h}$ at $30^{\circ} \mathrm{C}$ in a medium containing (per $1,000 \mathrm{ml}$ of deionized water) $20 \mathrm{~g}$ of potato dextrin, $15 \mathrm{~g}$ of Nutrisoy flour, $2.5 \mathrm{~g}$ of yeast extract, $5 \mathrm{~g}$ of glucose, and $1 \mathrm{~g}$ of $\mathrm{CaCO}_{3}$. After incubation, the cells were harvested by centrifugation, washed twice with sterile water, and then used as inocula. Cultures were studied on ISP media 3 and 4 (17), ATCC medium 172 (6), Czapek solution agar (22), Anio Henssens agar (22), potato-carrot agar (22), and tap water agar (8).

Cultural observations. Characteristics were recorded after 21 days of incubation at $30^{\circ} \mathrm{C}$ by using methods recommended by Shirling and Gottlieb (17). The ISCC-NBS Centroid Color Charts (21) were used to determine color designations. Morphology was studied by using an optical light microscope and a scanning electron microscope.

Physiological tests. Methods recommended by Gordon et al. (8) were used for the physiological tests. Tolerance to $\mathrm{NaCl}$ was tested at concentrations between 1 and $15 \%$. The growth temperature range was determined by using temperatures between 5 and $50^{\circ} \mathrm{C}$. Phosphatase and urease activities were determined by the methods of Blazevic and Ederer (4).

Resistance to kasugamycin. Well-grown vegetative cells of 


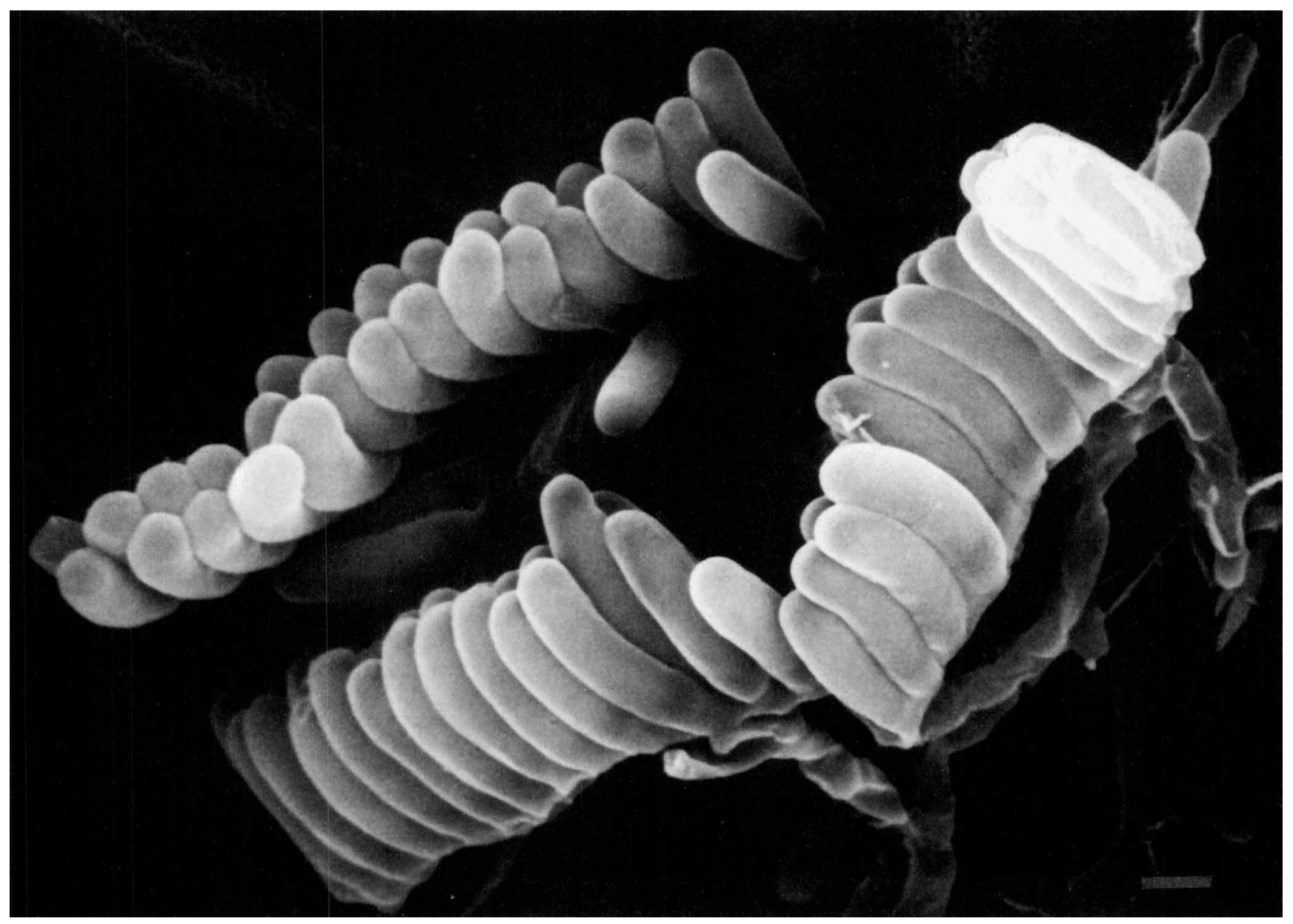

FIG. 1. Scanning electron micrograph of strain $\mathrm{A} 82600^{\mathrm{T}}$ grown on ATCC medium 172 for 14 days at $30^{\circ} \mathrm{C}$, showing parallel rows of sporangia with attached sporangiophores. Magnification, $\times 5,000$. Bar $=1.25 \mu \mathrm{m}$.

$\mathrm{A} 51460^{\mathrm{T}}$ and $\mathrm{A} 82600^{\mathrm{T}}$ were inoculated onto the surfaces of ATCC medium 172 preparations containing kasugamycin at predetermined concentrations. The preparations were incubated at $30^{\circ} \mathrm{C}$ for 10 days and then observed for growth.

Chemotaxonomy. Whole-cell hydrolysates prepared from washed, lyophilized, 72-h vegetative growth were examined by the methods of Becker et al. (3) and Lechevalier and Lechevalier (11). The madurose determination method used was based on a thin-layer chromatographic method described by Meyertons et al. (13). The mycolic acid determination technique used was based on techniques described by Minnikin et al. (15). Phospholipids were extracted with $\mathrm{CHCl}_{3}$, chromatographed on Silica Gel $60 \mathrm{~F}_{254}$ thin-layer chromatography plates by using $\mathrm{CHCl}_{3}$-methanol-concentrated $\mathrm{NH}_{4} \mathrm{OH}$ (200:120:15, $\mathrm{vol} / \mathrm{vol}$ ) and phospholipid standards (2), and visualized with a $10 \%$ ethanolic molybdophosphoric acid spray (7). The menaquinones were extracted with chloroform-methanol $(2: 1, \mathrm{vol} /$ vol) and were partially purified by thin-layer chromatography. Menaquinone composition was determined by high-performance liquid chromatography, using a Bondapak C18 column and a $\mathrm{CH}_{3} \mathrm{CN}-\left(\mathrm{CH}_{3}\right)_{2} \mathrm{CHOH}(3: 1, \mathrm{vol} / \mathrm{vol})$ eluent system. Each isoprenolog was detected at $254 \mathrm{~nm}$ at a temperature of $40^{\circ} \mathrm{C}$. The methods used were those of Collins (5) and Kroppenstedt (9).

Fatty acid analysis. Whole cells grown for $96 \mathrm{~h}$ in shaken flasks containing Trypticase soy broth at $28^{\circ} \mathrm{C}$ were saponified, methylated, and extracted as described by Miller and Berger (14). The fatty acid methyl esters were analyzed by gas-liquid chromatography with a model 5898A computer-controlled gas-liquid chromatography system (Hewlett-Packard Co., Palo Alto, Calif.). Fatty acids were identified by using data from a fatty acid library and a calibration mixture containing known fatty acids as a reference. A dendrogram based on Euclidian distances was generated with a computer. A two-dimensional principal-component analysis graph was also computer generated (1).

Scanning electron microscopy. Cultures were fixed in osmium tetroxide vapors for $20 \mathrm{~h}$ at room temperature, dehydrated by using an ascending ethanol series, transferred to $100 \%$ acetone, critical point dried with Freon-13, and sputter coated twice with gold-palladium. The cultures were examined with a Philips model 501-B scanning electron microscope.

\section{RESULTS AND DISCUSSION}

Chemotaxonomy. Hydrolyzed strain $\mathrm{A} 51460^{\mathrm{T}}$ and A82600 whole cells contained meso-diaminopimelic acid. The diagnostic sugars in the whole-cell extracts were galactose, madurose, and xylose. The phospholipids present were diphosphatidylglycerol, phosphatidylglycerol, phosphatidylinositol, phos- 


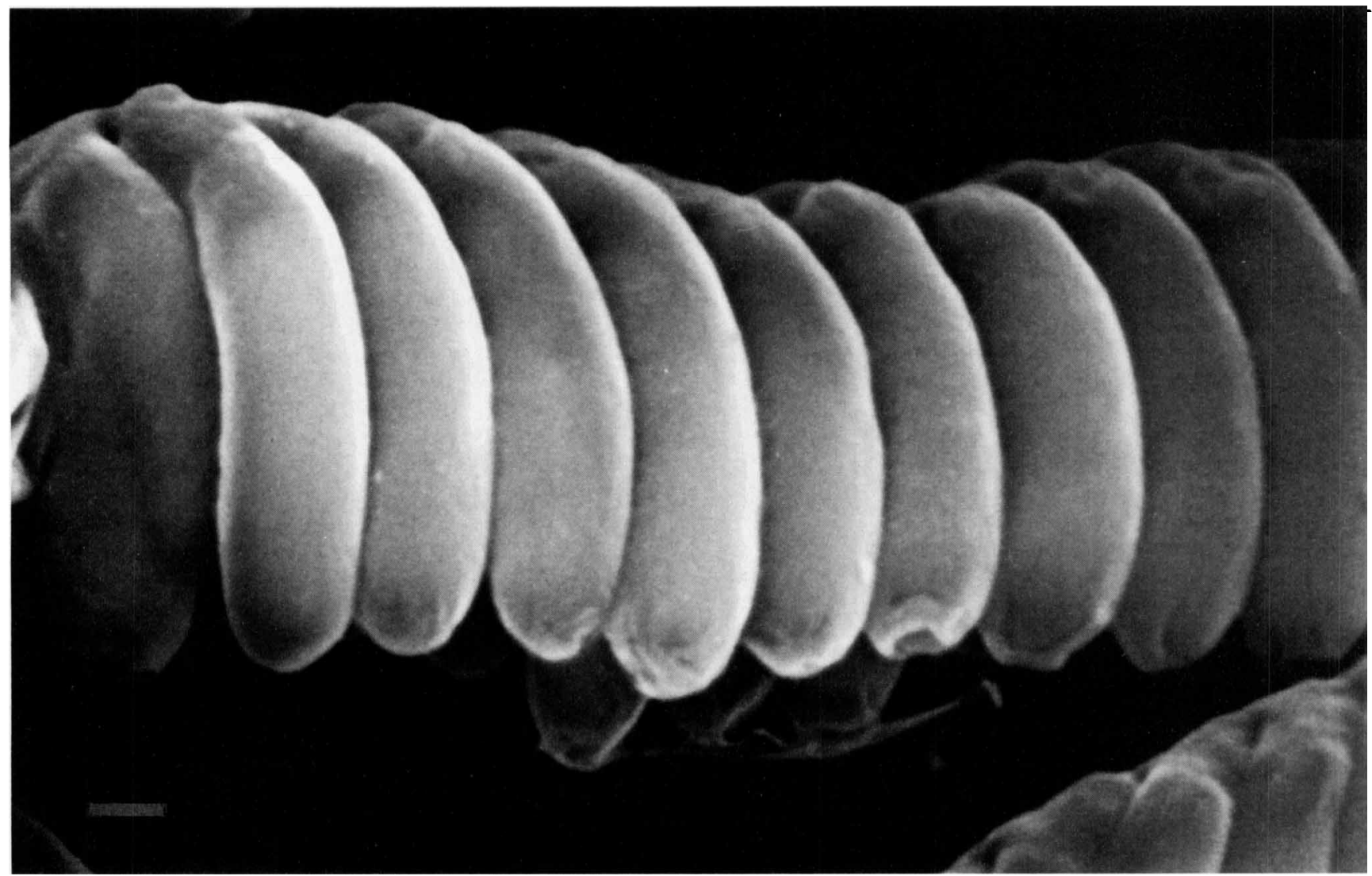

FIG. 2. Scanning electron micrograph of strain $\mathrm{A} 51460^{\mathrm{T}}$ grown on ATCC medium 172 for 14 days at $30^{\circ} \mathrm{C}$, showing rows of sporangia with single enclosed spores and opercula through which the single sporangiospores emerge. Magnification, $\times 10,000$. Bar $=0.56 \mu \mathrm{m}$.

phatidylethanolamine, hydroxyphosphatidylethanolamine, and glucosamine-containing phospholipids. Thus, strains A51460 and $\mathrm{A} 82600^{\mathrm{T}}$ have a type III cell wall composition, a type $\mathrm{B}$ whole-cell sugar pattern (10), and a type PIV phospholipid pattern (12). Mycolic acids were not present in the whole-cell hydrolysates. The major menaquinone detected was MK$9\left(\mathrm{H}_{2}\right)$; minor amounts of MK- $9\left(\mathrm{H}_{4}\right)$ were also detected.

Morphological characteristics. Neither strain $\mathrm{A} 51460^{\mathrm{T}}$ nor strain $\mathrm{A} 82600^{\mathrm{T}}$ exhibited fragmentation. Aerial hyphae were produced on most media. The aerial hyphae produced sporangiophores bearing long parallel rows of large sporangia which resembled rows of bananas (Fig. 1 and 2). Each of the sporangia contained a single large cylindrical to obclavate spore which became motile after immersion in water for 30 to $60 \mathrm{~min}$. The average spore size was 4.4 by $1.5 \mu \mathrm{m}$ (range, 3.5 to 5.4 by 1.4 to $1.6 \mu \mathrm{m}$ ). Isolate $\mathrm{A} 51460^{\mathrm{T}}$ formed large spherical bodies when it was grown on ISP medium 4 (Fig. 3). These large spherical bodies apparently can germinate; Fig. 4 shows the formation of promycelia or germ tubes. These spherical bodies were not observed on other media that were examined microscopically.

Cultural characteristics. Strains $A 51460^{\mathrm{T}}$ and $\mathrm{A} 82600^{\mathrm{T}}$ grew well on both complex and defined media. Aerial hyphae were produced on most of the media used. The aerial spore mass color of $\mathrm{A} 51460^{\mathrm{T}}$ was pink or sometimes white, and the reverse was yellowish pink to a distinctive reddish orange. The aerial spore mass color of $\mathrm{A} 82600^{\mathrm{T}}$ was white, and the reverse was grayish yellow. No soluble pigment was produced. The cultural characteristics of the two strains are shown in Table 1.
Physiological characteristics. The physiological characteristics of isolates $\mathrm{A} 51460^{\mathrm{T}}$ and $\mathrm{A} 82600^{\mathrm{T}}$ are given in Table 2 and in the descriptions of the two new species below.

Biological activity. Isolate $\mathrm{A} 51460^{\mathrm{T}}$ produced biological activity identified as the antibiotic thiostrepton. Isolate A82600 ${ }^{\mathrm{T}}$ produced an unknown biological activity that was active against gram-positive microorganisms and algae, exhibited antihelminthic activity, and produced an activity that was inhibitory to bovine mastitis.

Identity of genus. The type species of the genus Planomonospora is Planomonospora parontospora. This genus was described by Thiemann et al. (20) as follows. The organisms form branching vegetative hyphae that have no tendency to fragment. The aerial hyphae produce distinctive sporangia arranged in parallel rows bent in a characteristic fashion. Each sporangium contains a single large motile spore. No endospores, sheaths, synnemata, or sclerotia are present. The species are gram-positive, non-acid-fast, mesophilic, aerobic, catalase-positive, nonmotile organisms that have type III cell walls (type B whole-cell sugar pattern plus madurose); mycolates are absent. The predominant menaquinones are MK$9\left(\mathrm{H}_{2}, \mathrm{H}_{4}\right)$, and the phospholipid pattern type is type PIV. The guanine-plus-cytosine content of the DNA is $72 \mathrm{~mol} \%$. Soil actinomycete strains $\mathrm{A} 51460^{\mathrm{T}}$ and $\mathrm{A} 82600^{\mathrm{T}}$ are characterized by the properties described above. Both isolates have a type B whole-cell sugar pattern, and madurose is present. These chemotaxonomic characteristics plus the cultural and morphological properties of isolates $A 51460^{\mathrm{T}}$ and $A 82600^{\mathrm{T}}$ place these two strains in the genus Planomonospora. Previously, the 


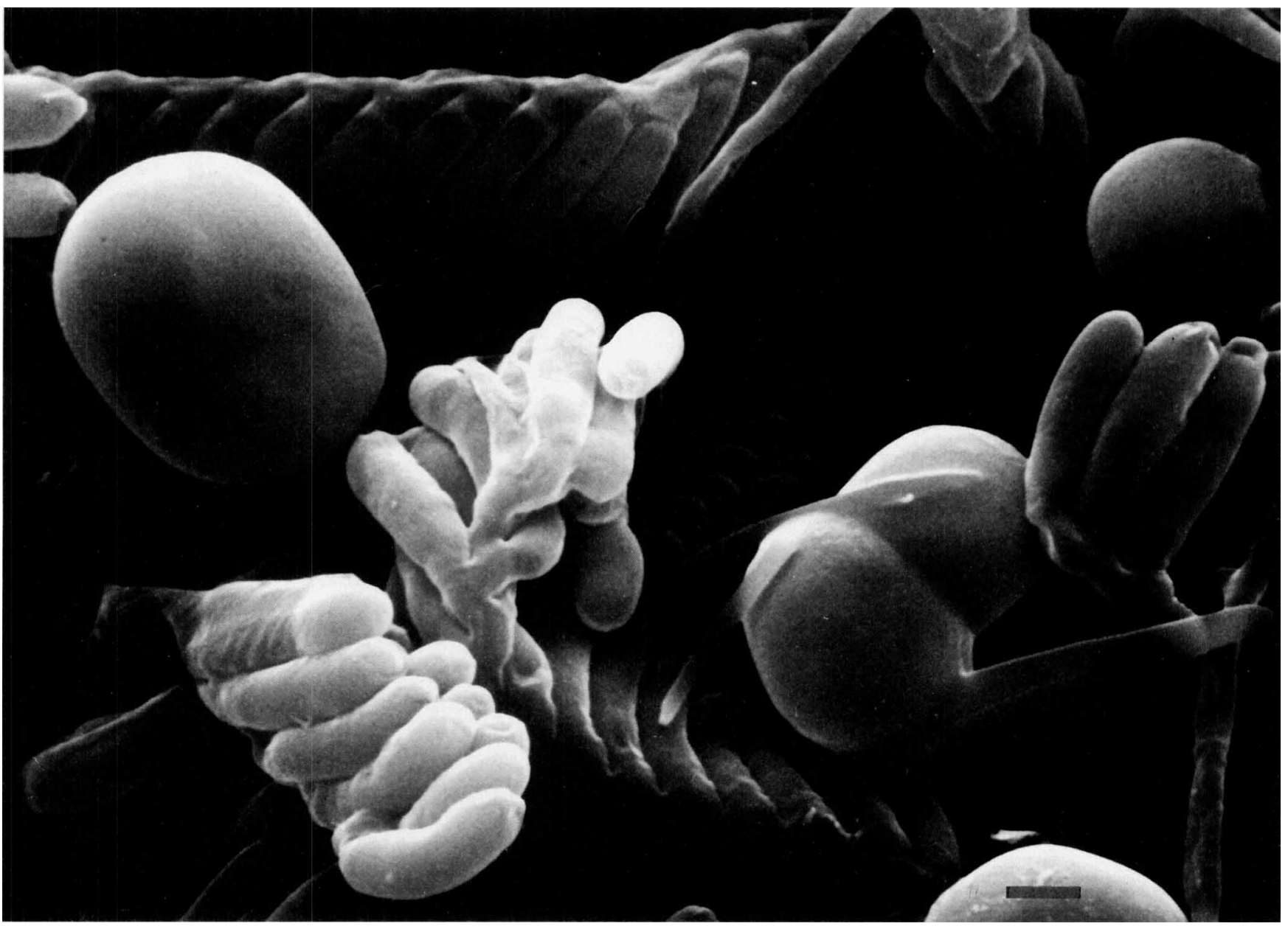

FIG. 3. Scanning electron micrograph of strain A51460 $0^{\mathrm{T}}$ grown on ISP medium 4 for 14 days at $30^{\circ} \mathrm{C}$, showing parallel rows of sporangia and a large spherical body. Magnification, $\times 5,000$. Bar $=1.19 \mu \mathrm{m}$.

following taxa have been described in this genus: Planomonospora parontospora subsp. parontospora, Planomonospora parontospora subsp. antibiotica, and Planomonospora venezuelensis.

Identity of species. Cultural, physiological, morphological, and fatty acid characteristics of strains $A 51460^{\mathrm{T}}$ and $\mathrm{A} 82600^{\mathrm{T}}$ were determined and were compared with characteristics of other strains belonging to the genus Planomonospora. Both strains were significantly different from previously described strains. The differences are discussed below.

Taxonomic characteristics of strains $\mathrm{A} 51460^{\mathrm{T}}$ and $\mathrm{A} 82600^{\mathrm{T}}$ and other type strains were compared. Strains A51460 ${ }^{\mathrm{T}}$ and $A 82600^{\mathrm{T}}$ differed from each other in the ability to reduce nitrate in the ability to utilize succinate, glycerol, and glycogen, and in the range of growth temperatures. The two strains had different aerial and substrate characteristics. Strain A51460 produced unique spherical bodies that were not observed in any other species. Strains $A 51460^{\mathrm{T}}$ and $\mathrm{A} 82600^{\mathrm{T}}$ differed from the other type strains in a variety of properties (Table 2).

The profile of fatty acids extracted from whole cells provides a fingerprint of a species, and a fatty acid pattern may be characteristic of a genus (16). A fatty acid analysis was performed with strains $\mathrm{A} 51460^{\mathrm{T}}$ and $\mathrm{A} 82600^{\mathrm{T}}$ and the other Planomonospora type strains. Table 3 shows the fatty acid compositions of these organisms. An examination of the data revealed considerable variation between $A 51460^{\mathrm{T}}$ and $\mathrm{A} 82600^{\mathrm{T}}$ in a number of fatty acids. The levels of the following fatty acids differed significantly: iso-14:0, 15:0, iso-16:1 G, 17:0, 17:1 C, and iso-18:1 F. The dendrogram in Fig. 5 shows the relationships of $\mathrm{A} 51460^{\mathrm{T}}$ and $\mathrm{A} 82600^{\mathrm{T}}$ to other Planomonospora, Planobispora, and Actinoplanes species. Strains that exhibit levels of relatedness (Euclidean distances) of less than 10.00 are considered members of the same species. A51460 and $\mathrm{A} 82600^{\mathrm{T}}$ are related to each other at a Euclidan distance of 13.00 and are related to no other cluster at a Euclidean distance of less than 20.00. Data from the dendrogram (not shown in Fig. 5) indicate that Planomonospora parontospora subsp. parontospora and Planomonospora parontospora subsp. antibiotica are related at a Euclidan distance of 6; this value suggests that the taxonomic positions of these subspecies need to be reexamined. Principal-component data (Fig. 6) indicate that both subspecies belong in the Planomonospora parontospora cluster, as described below.

Principal-component analysis is a branch of multivariate statistics that deals with the internal relationships of a set of variables. In principal-component analysis the greatest amounts of variance in original data or test results are expressed as principal components (1). A two-dimensional principal-component plot based on fatty acids is shown in Fig. 6 . The values indicate the degrees of separation between strains. 


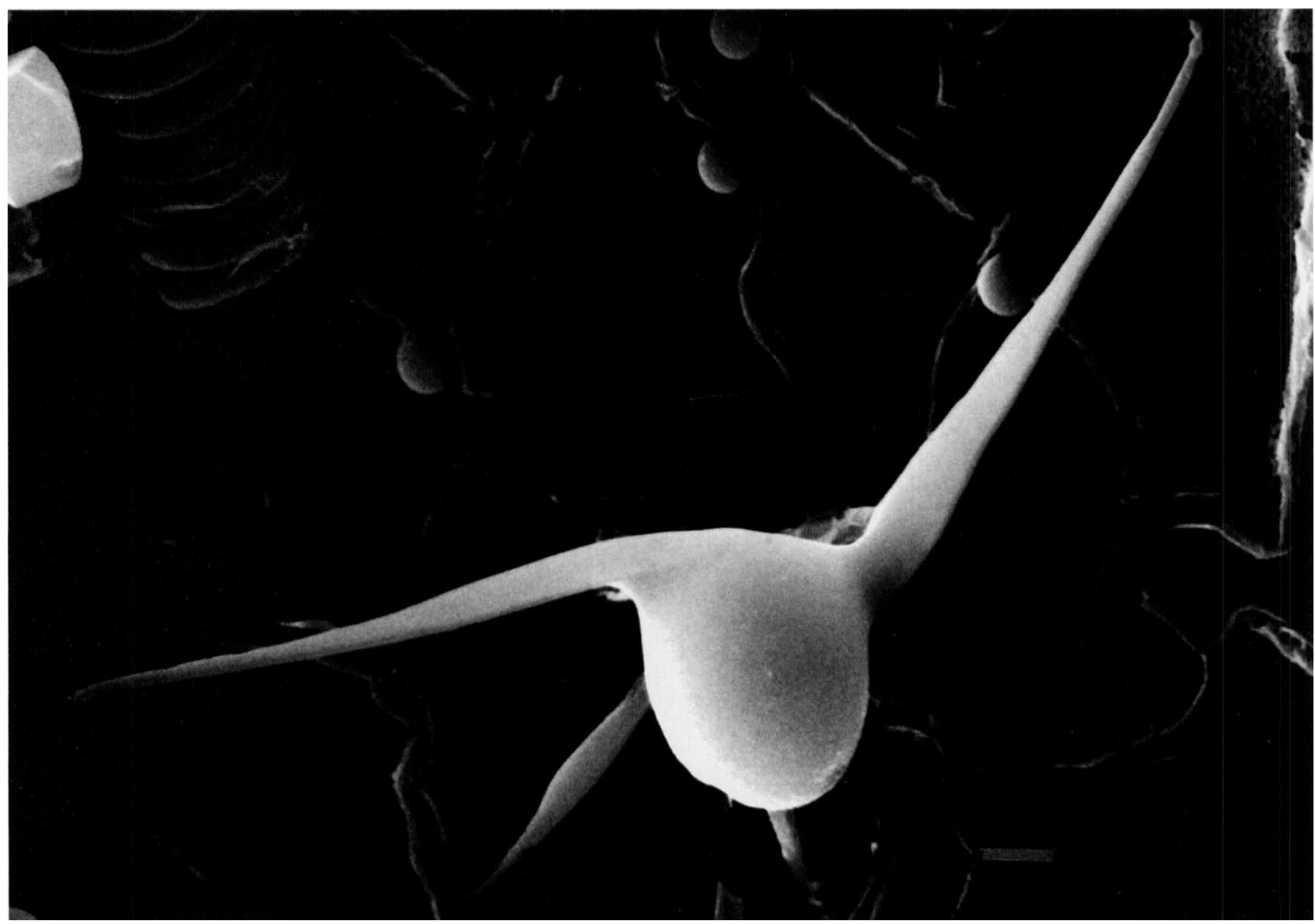

FIG. 4. Scanning electron micrograph of strain A51460 ${ }^{\mathrm{T}}$ grown on ISP medium 4 for 14 days at $30^{\circ} \mathrm{C}$, showing germination of a spherical body by production of promycelia. Magnification, $\times 4,000$. Bar $=1.47 \mu \mathrm{m}$.

An examination of this principal-component plot showed that both $\mathrm{A} 51460^{\mathrm{T}}$ and $\mathrm{A} 82600^{\mathrm{T}}$ are considerable distances from the type species clusters. This lack of clustering indicates that these strains are members of separate species.

All of the data described above indicate that $A 51460^{\mathrm{T}}$ and $\mathrm{A} 82600^{\mathrm{T}}$ are representatives of new species belonging to the genus Planomonospora. The name Planomonospora sphaerica sp. nov. is proposed for strain $\mathrm{A} 51460^{\mathrm{T}}$, and the name Planomonospora alba sp. nov. is proposed for strain $\mathrm{A} 82600^{\mathrm{T}}$.

Planomonospora sphaerica sp. nov. Planomonospora sphaerica (sphae'ri.ca. L. adj. sphaerica, spherical, referring to the presence of spherical bodies). Cells are aerobic, nonmotile, not

TABLE 1. Cultural characteristics of $A 51460^{\mathrm{T}}$ and $\mathrm{A} 82600^{\mathrm{T}}$ grown at $30^{\circ} \mathrm{C}$ for 21 days $^{a}$

\begin{tabular}{|c|c|c|c|c|c|}
\hline Strain & Medium & Growth & Reverse color & Aerial growth & Aerial color \\
\hline \multirow[t]{7}{*}{$A 51460^{T}$} & Anio Henssens agar & Good & 30.d.y (pink) & None & None \\
\hline & ATCC medium 172 & Abundant & 26.s.y (pink) & Abundant & $7 c a$ l.y (pink) \\
\hline & Czapek agar & Good & 28.1.y (pink) & Good & $b$ (white) \\
\hline & ISP medium 3 & Good & 28.1.y (pink) & Good & $b$ (white) \\
\hline & ISP medium 4 & Abundant & 37.m.rO. & Good & $7 c a$ l.y (pink) \\
\hline & Potato-carrot agar & Good & 28.1.y (pink) & Good & $b$ (white) \\
\hline & Tap water agar & Fair & 31.p.y (pink) & Fair & $b$ (white) \\
\hline \multirow[t]{7}{*}{$\mathrm{A} 82600^{\mathrm{T}}$} & Anio Henssens agar & Good & 92.y (white) & Good & $b$ (white) \\
\hline & ATCC medium 172 & Abundant & 90.gy (yellow) & Abundant & $b$ (white) \\
\hline & Czapek agar & Good & 90. gy (yellow) & Good & $b$ (white) \\
\hline & ISP medium 3 & Good & 93.y (gray) & Fair & $d l$ (gray) \\
\hline & ISP medium 4 & Abundant & 90.gy (yellow) & Good & $b$ (white) \\
\hline & Potato-carrot agar & Fair & 90.gy (yellow) & Fair & $d l$ (gray) \\
\hline & Tap water agar & Fair & 93.y (gray) & Poor & $b$ (white) \\
\hline
\end{tabular}

${ }^{a}$ Neither strain produced a soluble pigment on any medium. 
TABLE 2. Differential characteristics of strains $\mathrm{A} 51460^{\mathrm{T}}$ and $\mathrm{A} 82600^{\mathrm{T}}$ and other Planomonospora species and subspecies

\begin{tabular}{|c|c|c|c|c|c|}
\hline Characteristic & $\begin{array}{c}\text { Strain } \\
\text { A51460 }^{\mathrm{T}}\end{array}$ & $\begin{array}{c}\text { Strain } \\
\text { A82600 }^{\mathrm{T}}\end{array}$ & $\begin{array}{l}P . \text { parontospora subsp. } \\
\text { parontospora }\end{array}$ & $\begin{array}{l}\text { P. parontospora subsp. } \\
\text { antibiotica }\end{array}$ & P. venezuelensis \\
\hline \multicolumn{6}{|l|}{ Decomposition of: } \\
\hline Hypoxanthine & - & - & - & - & + \\
\hline Tyrosine & + & + & - & + & - \\
\hline Esculin & - & - & + & - & - \\
\hline \multicolumn{6}{|l|}{ Production of: } \\
\hline Nitrate reductase & + & - & + & + & + \\
\hline Phosphatase & + & + & + & - & + \\
\hline Gelatinase & + & + & - & + & - \\
\hline \multicolumn{6}{|l|}{ Utilization of: } \\
\hline L-Arabinose & + & + & - & + & - \\
\hline Cellobiose & + & + & - & + & - \\
\hline Citrate & + & + & + & + & - \\
\hline Dextrin & + & + & - & + & - \\
\hline Fructose & + & + & + & + & - \\
\hline D-Galactose & + & + & + & + & - \\
\hline Glycerol & - & + & - & - & - \\
\hline Glycogen & + & - & - & + & - \\
\hline Maltose & + & + & - & + & - \\
\hline D-Mannitol & + & + & - & + & - \\
\hline Mannose & + & + & - & + & - \\
\hline L-Rhamnose & + & + & - & - & - \\
\hline Salicin & - & - & - & + & - \\
\hline Succinate & + & - & - & + & - \\
\hline Starch & + & + & - & + & - \\
\hline Sucrose & + & + & - & + & - \\
\hline Trehalose & + & + & - & + & - \\
\hline D-Xylose & + & + & - & + & - \\
\hline Resistance to $5 \% \mathrm{NaCl}$ & - & - & - & + & - \\
\hline \multicolumn{6}{|l|}{ Growth at: } \\
\hline $15^{\circ} \mathrm{C}$ & - & - & - & + & - \\
\hline $45^{\circ} \mathrm{C}$ & - & + & - & - & - \\
\hline \multicolumn{6}{|l|}{ Color of aerial mycelium } \\
\hline White & - & + & - & - & - \\
\hline Pink & + & - & + & + & + \\
\hline Spherical body production & + & - & - & - & - \\
\hline Survives $50^{\circ} \mathrm{C}$ for $8 \mathrm{~h}$ & + & + & + & - & - \\
\hline
\end{tabular}

TABLE 3. Fatty acid compositions of strains $\mathrm{A} 51460^{\mathrm{T}}$ and $\mathrm{A} 82600^{\mathrm{T}}$ and other Planomonospora species and subspecies

\begin{tabular}{|c|c|c|c|c|c|}
\hline \multirow[b]{2}{*}{ Fatty acid ${ }^{a}$} & \multicolumn{5}{|c|}{$\%$ in: } \\
\hline & $\begin{array}{c}\text { Strain } \\
\text { A51460 }\end{array}$ & $\begin{array}{c}\text { Strain } \\
\text { A82600 }\end{array}$ & $\begin{array}{c}\text { P. parontospora subsp. } \\
\text { parontospora }\end{array}$ & $\begin{array}{c}\text { P. parontospora subsp. } \\
\text { antibiotica }\end{array}$ & P. venezuelensis \\
\hline $13: 0$ & 3.14 & 2.22 & 2.72 & 5.22 & 3.97 \\
\hline iso- $14: 0$ & 3.82 & 1.57 & 2.18 & 4.32 & 1.25 \\
\hline $14: 0$ & 0.93 & 1.35 & 1.33 & 1.29 & 2.11 \\
\hline $15: 0$ & 9.85 & 18.73 & 8.30 & 12.18 & 9.78 \\
\hline iso- $16: 1 \mathrm{~F}$ & 1.81 & 0.00 & 0.00 & 0.00 & 0.00 \\
\hline iso- $16: 1 \mathrm{G}$ & 0.00 & 2.63 & 1.17 & 1.67 & 0.00 \\
\hline iso- $16: 0$ & 7.91 & 8.47 & 7.25 & 5.70 & 5.13 \\
\hline $16: 1 \mathrm{cis}-9$ & 1.46 & 2.14 & 5.56 & 2.29 & 4.93 \\
\hline $16: 0$ & 1.82 & 2.63 & 5.51 & 1.51 & 7.86 \\
\hline 2-OH-15:0 & 0.32 & 1.01 & 0.0 & 0.78 & 0.44 \\
\hline iso- $17: 1 \mathrm{G}$ & 0.58 & 0.73 & 0.67 & 0.37 & 1.01 \\
\hline $17: 1 \mathrm{~B}$ & 22.67 & 23.96 & 34.27 & 36.84 & 26.11 \\
\hline $17: 1 \mathrm{C}$ & 0.65 & 2.32 & 0.70 & 1.22 & 0.00 \\
\hline $17: 0$ & 7.25 & 4.88 & 10.43 & 3.30 & 8.04 \\
\hline iso- $18: 1 \mathrm{~F}$ & 29.65 & 19.97 & 14.55 & 15.70 & 11.84 \\
\hline $18: 2$ cis -9 & 0.91 & 1.97 & 0.0 & 1.28 & 6.74 \\
\hline $18: 1$ cis -9 & 2.15 & 1.69 & 2.59 & 1.82 & 6.03 \\
\hline $2-\mathrm{OH}-17: 0$ & 1.08 & 1.72 & 0.71 & 1.70 & 0.60 \\
\hline
\end{tabular}

${ }^{a} \mathrm{~F}$ and $\mathrm{G}$ refer to unknown configurations. 


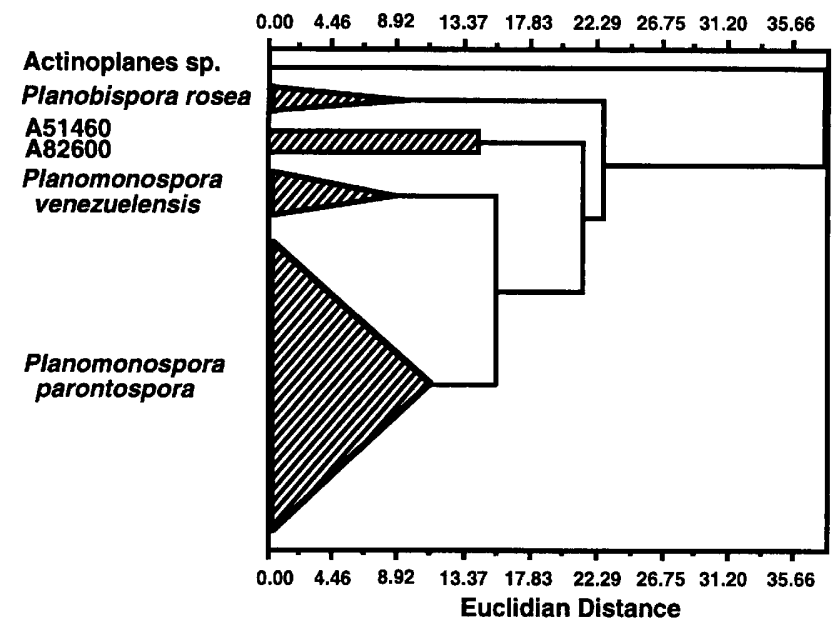

FIG. 5. Dendrogram showing the relationships among strain $\mathrm{A} 51460^{\mathrm{T}}$, strain $\mathrm{A} 82600^{\mathrm{T}}$, and Planomonospora, Planobispora, and Actinoplanes isolates, based on fatty acid profiles.

acid fast, gram positive, filamentous, and differentiated into substrate and aerial hyphae with a diameter of $1.0 \mu \mathrm{m}$. There is no tendency to fragment. The aerial hyphae are pink, and the vegetative mycelium is yellowish pink. No soluble pigment is produced. Aerial hyphae produce sporangiophores bearing long parallel rows of large sporangia which resemble rows of bananas. Each sporangium contains a single large cylindrical to obclavate spore which becomes motile after immersion in water for 30 to $60 \mathrm{~min}$. The average spore size is 4.4 by $1.5 \mu \mathrm{m}$ (range, 3.5 to 5.4 by 1.4 to $1.6 \mu \mathrm{m}$ ). Utilizes the carbohydrates D-glucose, $l$-arabinose, cellobiose, dextrin, $d$-fructose, D-galactose, glycogen, $d$-maltose, D-mannitol, D-mannose, L-rhamnose, starch, sucrose, trehalose, and D-xylose, but not adonitol, D-arabinose, cellulose, dulcitol, ethanol, erythritol, $\alpha$-methylD-glucoside, glycerol, inositol, inulin, lactose, melezitose, melibiose, raffinose, D-ribose, salicin, sorbitol, and L-sorbose. Sodium salts of the following organic acids are utilized as sole sources of carbon for energy and growth: acetate, butyrate, lactate, pyruvate, and succinate. Benzoate, citrate, malate,

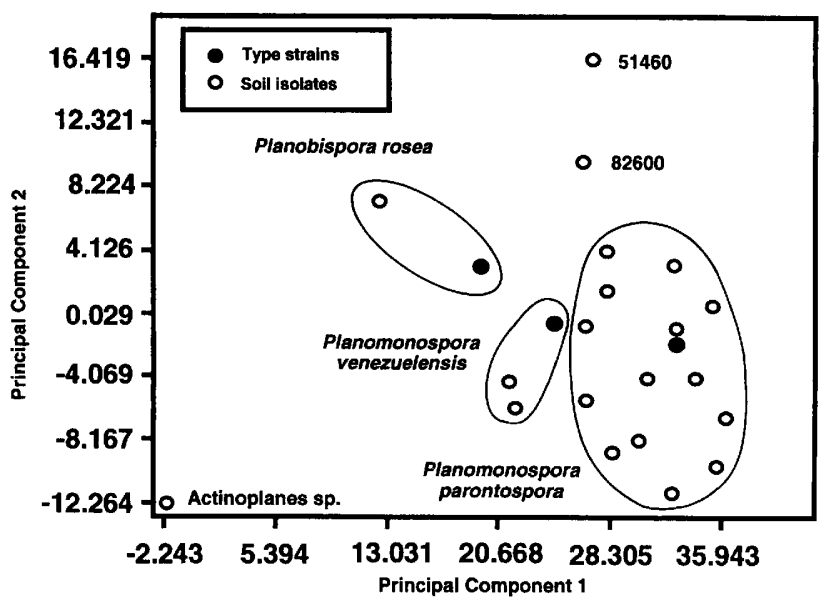

FIG. 6. Two-dimensional principal-component analysis plot based on fatty acid profile data, differentiating strains $A 51460^{\mathrm{T}}$ and $\mathrm{A} 82600^{\mathrm{T}}$ from previously described Planomonospora, Planobispora, and Actinoplanes species. mucate, oxalate, propionate, and tartrate are not utilized. Hydrolyzes casein and DNA and decomposes L-tyrosine but not adenine, xanthine, calcium-malate, esculin, hippurate, or hypoxanthine. Produces urease, phosphatase, and gelatinase, survives exposure to $50^{\circ} \mathrm{C}$ for $8 \mathrm{~h}$, reduces nitrate, grows at temperatures between 20 and $42^{\circ} \mathrm{C}$, tolerates $\mathrm{NaCl}$ only at a concentration of $2 \%$, and is resistant to $2.0 \mu \mathrm{g}$ of kasugamycin per ml. Type III cell wall composition, type B whole-cell sugar pattern, and type PIV phospholipid pattern. Mycolic acids are absent. The major menaquinone detected is MK- $9\left(\mathrm{H}_{2}\right)$; minor amounts of MK-9 $\left(\mathrm{H}_{4}\right)$ are also present. Strain A51460 ${ }^{\mathrm{T}}$ differs from other Planomonospora strains in fatty acid composition (Table 3) and in morphological, cultural, and physiological characteristics (Tables 1 and 2).

Type strain. The type strain is A51460 (= NRRL 18923). This strain was isolated from soil collected in India. The species description is based on a single strain and thus serves as the type strain description.

Planomonospora alba sp. nov. Planomonospora alba (al'ba. L. adj. alba, white, referring to the white aerial hyphae). Cells are aerobic, nonmotile, not acid fast, gram positive, filamentous, and differentiated into substrate and aerial hyphae with a diameter of $1.0 \mu \mathrm{m}$. There is no tendency to fragment. The aerial hyphae are white, and the vegetative mycelium is grayish yellow. No soluble pigment is produced. Aerial hyphae produce sporangiophores bearing long parallel rows of large sporangia which resemble rows of bananas. Each sporangium contains a single large cylindrical to obclavate spore which becomes motile after immersion in water for 30 to $60 \mathrm{~min}$. The average spore size is 4.4 by $1.5 \mu \mathrm{m}$ (range, 3.5 to 5.4 by 1.4 to $1.6 \mu \mathrm{m})$. Utilizes the carbohydrates D-glucose, $l$-arabinose, cellobiose, dextrin, $d$-fructose, D-galactose, glycerol, maltose, D-mannitol, D-mannose, L-rhamnose, starch, sucrose, trehalose, and D-xylose, but not adonitol, D-arabinose, cellulose, dulcitol, ethanol, erythritol, $\alpha$-methyl-D-glucoside, glycogen, inositol, inulin, lactose, melezitose, melibiose, raffinose, Dribose, salicin, D-sorbitol, and L-sorbose. Sodium salts of the following organic acids are utilized as sole sources of carbon for energy and growth: acetate, butyrate, lactate, and pyruvate. Benzoate, citrate, malate, mucate, oxalate, propionate, succinate, and tartrate are not utilized. Hydrolyzes casein and DNA and decomposes L-tyrosine but not adenine, xanthine, calciummalate, esculin, hippurate, or hypoxanthine. Produces urease, phosphatase, and gelatinase, survives exposure to $50^{\circ} \mathrm{C}$ for $8 \mathrm{~h}$, grows at temperatures between 20 and $50^{\circ} \mathrm{C}$, is not able to reduce nitrate, tolerates $\mathrm{NaCl}$ only at a concentration of $2 \%$, and is resistant to $2.0 \mu \mathrm{g}$ of kasugamycin per ml. Type III cell wall composition, type B whole-cell sugar pattern, and type PIV phospholipid pattern. Mycolic acids are not present. The major menaquinone detected is $\mathrm{MK}-9\left(\mathrm{H}_{2}\right)$; minor amounts of MK-9 $\left(\mathrm{H}_{4}\right)$ are also present. Strain A82600 ${ }^{\mathrm{T}}$ differs from other Planomonospora strains in fatty acid composition (Table 3 ) and in morphological, cultural, and physiological characteristics (Tables 1 and 2).

Type strain. The type strain is A82600 (= NRRL 18924), which was isolated from soil collected in The Sudan. The species description is based on a single strain and thus serves as the type strain description.

\section{ACKNOWLEDGMENTS}

I thank Sandy White, Eli Lilly \& Co., Indianapolis, Ind., for her skillful technical assistance in obtaining the scanning electron micrographs. Menaquinone determinations and phospholipid analyses were performed by Reiner M. Kroppenstedt, Deutsche Sammlung von Mikroorganismen und Zellkulturen, Braunschweig, Germany. 


\section{REFERENCES}

1. Alderson, G. 1985. The application and relevance of nonhierarchic methods in bacterial taxonomy, p. 227-263. In M. Goodfellow, D. Jones, and F. G. Priest (ed.), Computer-assisted bacterial systematics. Academic Press, New York.

2. Ames, G. F. 1968. Lipids of Salmonella typhimurium and Escherichia coli: structure and metabolism. J. Bacteriol. 95:833-842.

3. Becker, B., M. P. Lechevalier, R. E. Gordon, and H. E. Lechevalier. 1964. Rapid differentiation between Nocardia and Streptomyces by paper chromatography of whole-cell hydrolysates. Appl. Microbiol. 12:421-423.

4. Blazevic, D. J., and G. M. Ederer. 1975. Principles of biochemical tests in diagnostic microbiology. John Wiley \& Sons, Inc., New York.

5. Collins, M. D. 1985. Isoprenoid quinone analysis in bacterial classification and identification, p. 267-287. In M. Goodfellow and D. E. Minnikin (ed.), Chemical methods in bacterial systematics. Academic Press, New York.

6. Cote, R., P.-M. Daggett, M. J. Gantt, R. Hay, S.-C. Hay, and P. Pienta. 1984. ATCC media handbook, 1st ed. American Type Culture Collection, Rockville, Md.

7. Dittmer, J. C., and R. L. Lester. 1968. A simple, specific spray for the detection of phospholipids on thin-layer chromatograms. J. Lipid Res. 5:126-127.

8. Gordon, R. E., D. A. Barnett, J. E. Handerhan, and C. Pang. 1974. Nocardia coeliaca, Nocardia autotrophica, and the Nocardin strain. Int. J. Syst. Bacteriol. 24:54-63.

9. Kroppenstedt, R. M. 1985. Fatty acid and menaquinone analysis of actinomycetes and related organisms, p. 173-199. In M. Goodfellow and D. E. Minnikin (ed.), Chemical methods in bacterial systematics. Academic Press, New York.

10. Lechevalier, M. P., and H. Lechevalier. 1970. Chemical composition as a criterion in the classification of aerobic actinomycetes. Int. J. Syst. Bacteriol. 20:435-443.

11. Lechevalier, M. P., and H. Lechevalier. 1980. A university laboratory approach, p. 227-233. In A. Dietz and D. W. Thayer (ed.), A university laboratory approach. Society for Industrial Microbiology Special Publication no. 6. Society for Industrial Microbiology, Arlington, Va.
12. Lechevalier, M. P., A. E. Stern, and H. A. Lechevalier. 1981. Phospholipids in the taxonomy of actinomycetes, p. 111-123. In K. P. Schaal and G. Pulverer (ed.), Actinomycetes. Gustav Fischer Verlag, New York.

13. Meyertons, J. L., D. P. Labeda, G. L. Cote, and M. P. Lechevalier. 1988. A new thin-layer chromatographic method for whole-cell sugar analysis of Micromonospora species. Actinomycetes 20:182192.

14. Miller, L., and T. Berger. 1985. Bacterial identification by gas chromatography of whole cell fatty acids. Hewlett-Packard Application Note 228-41. Hewlett-Packard Co., Palo Alto, Calif.

15. Minnikin, D. E., I. G. Hutchinson, and A. B. Caldicott. 1980. Thin-layer chromatography of methanolysates of mycolic acidcontaining bacteria. J. Chromatogr. 188:221-233.

16. Mirza, J. D. J., D. Hahn, and A. D. L. Akkermans. 1991. Identification of atypical Frankia strains by fatty acid analysis. FEMS Microbiol. Lett. 83:91-98.

17. Shirling, E. B., and D. Gottlieb. 1966. Methods for characterization of Streptomyces species. Int. J. Syst. Bacteriol. 16:313-340.

18. Thiemann, J. E. 1970. Study of some new genera and species of the Actinoplanaceae, p. 245-257. In H. Prauser (ed.), The Actinomycetales. Veb Gustav Fischer Verlag, Jena, Germany.

19. Thiemann, J. E., C. Coronelli, H. Pagani, G. Beretta, G. Tamoni, and V. Arioli. 1968. Antibiotic production by new form-genera of the Actinomycetales. I. Sporangiomycin, an antibacterial agent isolated from Planomonospora parontospora var. antibiotica var. nov. J. Antibiot. 21(9):525-531.

20. Thiemann, J. E., H. Pagani, and G. Beretta. 1967. A new genus of the Actinoplanaceae: Planomonospora, gen. nov. G. Microbiol. 15:27-38.

21. U. S. Department of Commerce National Bureau of Standards. 1958. ISCC-NBS centroid color charts, standard sample no. 2106. U.S. Department of Commerce, Washington, D.C.

22. Waksman, S. A. 1961. The actinomycetes, vol. 2, p. 328-334. The Williams \& Wilkins Co., Baltimore.

23. Wingender, W., H. Hugo, and W. Frommer. 1975. A protease inhibitor isolated from Planomonospora parontospora. J. Antibiot. 28(8):611. 